\title{
Translocation of White Rhinoceros in South Africa
}

\author{
By Ian Player
}

The history of wildlife conservation in Africa is one of dwindling animal populations and shrinking habitats, and the southern white or square-lipped rhinoceros Ceratotherium simum simum became one of the rarest large mammals in Africa. This paper, on which the author's address at San Diego was based, describes one of the most successful operations in wildlife conservation, the build-up in numbers of the white rhino and the re-population of some of its former range, thanks largely to the use of immobilising drugs. Ian Player, who played a major part in the operations, is Chief Conservator of Zululand.

WHEN first seen by white man, the southern square-lipped rhinoceros ranged throughout southern Africa from the Orange and Umfolozi rivers in the south, to the Zambesi and Cunene rivers in the north. Between 1812, when Burchell first described it from Kuruman in the northern Cape Province, and the end of the century, the white rhino was exterminated throughout its range except in the relatively minute area at the junction of the Black and the White Umfolozi rivers in Zululand, Natal. This area is now inside the Umfolozi Game Reserve, which was proclaimed in 1897 through the efforts of Charles Saunders. In its first thirty-two years, however, this sanctuary for the white rhino was by no means secure, due to the tsetse fly game elimination campaigns. Lang" notes: "Before that most regrettable game butchery in 1920 there were, according to the Game Conservator's (Vaughan Kirby) own estimate twice as many" as the twenty-five subsequently left. In 1916 R. Symons, then relieving Game Conservator, saw no white rhino in the course of a six-week's tour from the western to the eastern extremities of the reserve, but he did see four in the unreserved land north of the Black Umfolozi (unpublished diary).

From $1930 \mathrm{Mr}$ Douglas Mitchell visited the reserve regularly. He noticed that rhino cows were leaving the reserve to the north and the west in order to calve, and that the majority of the calves were killed by Africans (pers. comm.). When in $1939 \mathrm{Mr}$ Mitchell was appointed a member of the Natal Administrator's executive committee, his first act in office was to get the decision to abolish the reserve rescinded, thus averting certain doom for the southern subspecies.

The subsequent history of the white rhino has been by no means uneventful, but by 1960 Lang's original proposal to transfer white rhino to other parts of its old range had become a practical possibility; it was also vitally necessary, for the rhino population explosion of the 
1940 's and 50's was cause for grave concern, not only because of limited food resources within the reserve but also because of the numbers of animals resident in vacant land that was soon to be settled by man. Both these problems are still only partially solved. Nevertheless the story is now of an expanding population recolonising parts at least of its once wide range. The problems encountered and the procedures developed in doing this are the subject of this paper.

\section{Physical characteristics}

Seven external characteristics readily distinguish the white rhino from the black Diceros bicornis: the nuchal hump, formed of muscular and epidermal tissue unsupported by bone ${ }^{1}$, which is of functional significance and forms part of the animal's adaptation to its way of life ${ }^{3}$; the much greater length and size of the head-a full grown adult head weighs $600 \mathrm{lb}$; the straight, wide, anterior margin of the lips, from which the alternative name is derived; the flat frontal surface of the base of the anterior horn; the greater bulk and height of the adults; the larger ears, prominently tipped with hairs; and the longer distance between the humps formed by the lumbar spines and the pelvis. The colour of both species is very similar, and depends largely on the colour of the mud in which they last wallowed. The white rhino formerly inhabited a wide variety of savanna vegetation types in subhumid to arid climatic zones, but not precipitous country or forests. The origin of the names "white" and "black" has always been controversial, but the theory that the early Boer hunters, because of the timidity of the white rhino and the aggressiveness of the black, likened the white rhino to the white man and the black to the fierce tribes of the interior, seems most probable.

The removal of the square-lipped rhino to former habitats in South Africa was first mooted in 1929 by the American Dr. Herbert Lang, who appreciated the political threats to the species. He advocated capture by nets and removal to the Kruger National Park, but it was not until 1960, with the imminent demarcation of new boundaries and the realisation that many rhino would be outside the proclaimed reserve, that a real effort was made to capture them.

\section{Drug Development}

In December 1960, Dr. A. M. Harthoorn, the eminent veterinary physiologist from East Africa, was invited to Natal to experiment with the latest drugs. The first drug, a paralysing one Gallamine triothiodide, used on a series of ten white rhino, was discontinued because of the narrow tolerance factor. In June 1961 Dr. Harthoorn experimented with a combination of Themalon (diethylthiambutene hydrochloride) and Sernyl (1-(1-Phenylcyclohexyl) piperidine monohydrochloride), and twelve white rhino immobilised with this all recovered. After darting some twenty minutes would elapse before the rhino went down, in which time it could travel up to five miles. Only three deaths from the actual drugs could be attributed to this combination, 
which was a big breakthrough. It was now possible to capture rhino ranging from 800 to $4000 \mathrm{lb}$.

The disadvantage of this combination was the large dosage required. The use of $20 \mathrm{cc}$ darts limited the darting range, and serious dart wounds also resulted on rhino put into bomas. Also we found that after the injection of the antidote some animals fought their crates and got their horns jammed, some of them dying as a result. So the use of Sernyl was discontinued for the white rhino, but retained for the black because without it the animal kept on moving.

In July 1963 Dr. Harthoorn, in conjunction with Reckitts, in England, made the new drug M99 available to us. By September 1963 it had been successfully used on wild rhinos. The optimum dose for white rhino was found to be $.5 \mathrm{mgm}$ M99 plus $1 \mathrm{mgm}$ Acetylpromazine per $1,000 \mathrm{lb}$ (Clark in litt.). The reaction time is between 8 to 12 minutes. When hyocine is added-100 mgm for a 2,000-5,000 lb animal-the reaction time is quicker, but it takes longer for the rhino to learn to eat in the boma. The use of M99 has simplified and streamlined the capture of the white rhino. The rapid immobilisation makes it possible to capture rhino in very dense bush and reduces injuries to horsemen and horses because of the shorter distances they have to follow the rhino. The small amounts of drugs required have reduced the size of the dart from $20 \mathrm{cc}$ to $3 \mathrm{cc}$, and as a result dart wounds no longer occur.

The M99 drug is put into the dart in this order: inject M99 and Acetylpromazine into rubber plunger; dissolve hyocine in $1 \mathrm{cc}$ of sterile $\mathrm{pH} 4$ water and inject into dart; top up with $\mathrm{pH} 4$ water and screw on needle immediately. Lethidrone (nalorphone hydrobromide) readily reverses the Themalon combination of drugs; after a $50 \mathrm{mgm}$ intravenous injection in the ear, a full grown 4,000 lb rhino can be on its feet within a minute. With $\mathrm{M} 99,500 \mathrm{mgm}$ has to be injected intravenously for rhino weighing $1,000-5,000 \mathrm{lb}$. Reaction time varies between five and ten minutes after the injection. Harthoorn discusses this drug fully".

\section{Firearms}

Two weapons have been most commonly used for the capture of rhino. One is the gas-powered Palmer Cap-chur gun. This is not accurate until the user is familiar with the weapon, for the range depends upon temperature and the amount of gas remaining. The dart is also slow moving in flight and easily deffected by wind or pieces of grass. Nevertheless, it has been the principal weapon and is still being used. It has advantages in very dense bush when rhino have to be darted at close range. Without the invention of this weapon the translocation of rhino would not have been a success.

The second weapon is the powder charge gun, which is a modified 32 gauge shotgun fitted with .303 rifle rear sight. Two types of cartridge, manufactured by A. S. Ruffel \& Co. of South Africa, enable the user to shoot from 30 to 60 yards or from 40 to 100 yards. 
Feathered flights are preferable to nylon tufted flights. In open country or in the capture of antelope this weapon has proved most useful.

\section{Techniques of Capture}

The techniques of capture developed by Natal Parks Board rangers during the early stages of "Operation Rhino" have not changed in detail ${ }^{4}$. The dart is fired either on foot or from a Land Rover, the horsemen follow the animal until it halts and can be restrained with rope, and then advise the men at the waiting truck, either by walkietalkie or by one horseman returning. The truck, which is equipped with winch, rollers and crate, is brought up and the crate unloaded in front of the rhino. The antidote Lethidrone, injected intravenously into an ear, onables the rhino to stand up and walk into the crate, using a steel plate placed against the crate as a step to help it. This became necessary because many rhino were tearing the skin near their toes. these wounds became septic, and because of the location were difficult to treat.

In areas such as river beds and the slopes of hills where it was not possible to get a truck, a small injection of antidote would be enough to get the rhino moving. It could then be led to a truck. On one occasion a fully grown adult was led for two miles in this fashion, much to the consternation of tourists and some local African women.

\section{The Use of Horses}

Steele (pers. comm.) says it is advisable to have two horsemen, particularly in thick bush, one to follow the rhino, the other to go to the nearest prominent point to see where the rhino emerges. He observed that until the drugs took effect, the rhino never hit trees, despite their bad eyesight. The rhino's reaction after darting was almost always to flee, but the wind direction often determined how far it would run. The initial disturbance, shouting, etc., was also a factor. If other rhinos were present and became disturbed the darted rhino would continue to run. Darted females appeared to run further than males, particularly adult males, which seemed reluctant to leave their territory. Keeping a darted animal in sight was easier when the dart remained in the animal, and those darted in the rump seldom lost it even when plunging through thick bush.

In two areas of the Umfolozi Reserve, the rhino would always run south towards certain thickets which are popular calving areas. Once a rhino was running there seemed to be little danger of the horses being crushed, but if it got behind the horses it often charged and tried to gore them. When a large group stopped, the rider would dismount and hold the horses' bits to stop the jangling upsetting the rhino. The situation the horsemen feared most was when rhino ran through buffalo herds, because buffalo would attack without warning, particularly if there were calves in the herd. The grunt of a warthog, the cry of a hadada bird or the whistle of a reedbuck was often enough to get a rhino running again. 
On the other hand the black rhino's first reaction on getting a fright was invariably to charge. This made darting simple. Once darted it would take flight, and only once did a darted animal wait for the following horsemen and charge. On one occasion a half-grown white rhino calf, accompanied by a large cow was darted. They ran into some dense bush, found they could not go over a 12-foot drop, and turned; the cow then tossed a $950 \mathrm{lb}$ horse eight feet into the air. Most of the horses soon got used to the work and became blasé, even the one that was gored. This cost the life of one of the famous "rhino following" horses, which nonchalantly went to drink at a pan where some rhinos were resting and was gored to death by an irate bull.

Some rhinos in a partially drugged state fell over cliffs and were killed, but sometimes the horsemen were able to turn a partially drugged rhino aside by shouting or alternatively by roping the animal's hind legs. In particularly dense thickets horses have to be protected from thorns, and for this, coronet guards and aprons are effective. Horsemen wear canvas jackets, crash helmets and gloves. Rainy-weather can be dangerous for the horsemen, for in trying to avoid buffalo or black rhino, the horses may slip. To revive rhinos which collapse while crossing rivers, horsemen carry phials of Lethidrone, an immediate intravenous injection is enough to get them on their feet and out of danger of drowning. Rhino had not been shot or disturbed for over thirty years, and it was interesting to note how quickly they became aware that they were being hunted.

Once the drugs and capture techniques had been successfully developed the Natal Parks Board authorised the export of square-lipped rhino to zoological gardens all over the world and to re-colonise former ranges in Africa. The operation developed in three main directions: translocation to zoological gardens and game reserves beyond a motorable distance, translocation to places within a 400 miles radius, and capture for marking, release and subsequent study in Umfolozi.

Of the three, the first has been the hardest to master, for it required completely new techniques in taming rhino while they were recovering from drugs.

\section{Taming after Capture}

Originally four pens on the East African trappers' pattern were built. Square and made of bush timber, they were subjected to a great deal of bashing by the rhino, which would fight for days to get out, attacking the pens in every conceivable manner including standing on their hind legs. The pens had an earth floor which the rhino tended to turn into a wallow, and concrete floors are now being used. On one occasion a large male escaped at night by climbing over a sixfoot gate (Clark in litt.). It managed to get its front legs over the gate bars, then wormed its way over until it was rocking on its belly. Ranger Clark came out, clad only in a shirt, in time to see the rhino come tumbling down. It was on its feet in a flash and chased Clark into a two ton crate which it hit and moved a good nine inches. 
Getting the rhinos to eat was often difficult. Sometimes one would be in captivity for sixteen days without eating, then five minutes after release it would be seen grazing within 50 yards of the pen. The time taken to start eating varied from four to fourteen days, the average being six. Indigenous grasses - Panicum sp. Urochloa sp. Themeda sp.-had to be fed to it first, gradually supplemented after two to three weeks by the exotic feeds teff and lucerne (alfalfa). Feeding was also complicated by the fact that rhino would rest during daylight and become active at night. When using the Themalon/ Largactil/hyocine mixture in the $20 \mathrm{cc}$ syringe bodies, we had great difficulty getting the rhino to eat. Dart wounds became septic and developed into huge abcesses into which a man could put his whole hand.

Each rhino has marked individuality. One animal was put off by constant attempts to get it to feed and eventually started eating only in the dead of night, when undisturbed. Another would eat only when the gate poles were rattled, which we attributed to the fact that, when it had almost fully recovered from the drug, some green grass Panicum maximum was thrown to it at the gate and the gate rattled to draw the animal's attention to it, the noise ever after being an essential feature in a conditioned reflex. One young animal which sulkily refused to eat for twelve days was force-fed with maize meal mixture. A hose from a stirrup pump was forced into its mouth while it lay resting, and thereafter it would only eat lying down.

Getting the animals to feed continued to be a serious problem until Ranger Clark discovered that by adding bicarbonate of soda to their drinking water the rhino would begin eating far sooner (Clark, in litt. 1966).

\section{Taming Young Calves}

Sometimes very young calves (three months plus) of females captured or dying of natural causes were brought in to the boma. Their smallness made it a simple matter to attend to their dart wounds and within a short period they would come to be fed upon being called at the rattle of a basin. They were given a mixture of skimmed milk, concentrates, salt and sugar via a brandy bottle, until after a few days they could be put on to indigenous green grasses, followed by lucerne (alfalfa). At a later stage some developed tiny skin sores all over the body, caused by vitamin deficiency. A vitamin B complex syrup added to the milk, with ascorbic acid injected intramuscularly, soon eliminated this.

Constipation after recovery from the drugs was always a problem. Fresh dung thrown into the pens would sometimes stimulate defecation. Twice Neostigmine was used by the muscular cramps must have been extremely painful, for the animal bellowed and was in a vicious mood. This was discontinued because of the dangerous consequences without expert veterinarian advice. (For full discussion of this drug see Harthoorn, 1965). Coarse cattle salt mixed with drinking water 
encouraged the intake of liquids which in turn aided defecation. In the early days some rhino had to be moved to the Kruger National Park before being completely tamed ${ }^{1}$. These animals defecated from fear during crating and from then on had normal movements.

Serious mortality occurred in July 1963 when Zululand experienced one of the worst floods in its history. At the time twelve rhino were in different stages of being tamed for export to various zoos. Fourteen inches of rain fell within a few hours, the Black Umfolozi river rose fifty feet, the whole game reserve was inundated, and water rushed three feet deep through the rhino bomas. Soon afterwards the weather turned cold and six rhino died from pneumonia and similar causes. It was a particularly trying time for Ranger Clark, the officer caring for the rhino.

Troubles with feeding and the treatment of dart wounds continued. So a cabled paddock eighty yards long was added to the bomas, and there was an immediate improvement in the condition of animals released into the paddock. The exercise caused the severe dart wounds to drain and made the rhino begin eating earlier.

Black Rhino Are Easier

Strange to relate, none of these problems was experienced with the black rhino, despite their aggressiveness in the wild. Most black rhino would be feeding within twenty-four hours, and in a few days would be so tame that dart wounds could be hand-dressed. The learning ability of the black rhino seems greater than that of the white. One female black rhino named Ngozi (Zulu-danger) had been caught in a cable snare which almost severed the neck muscles. Within a few days she was coming up to the gate to have her neck dressed and would turn it from side to side while the antibiotics were being powdered on. During convalescence this animal required bundles of grass every three or four days as well as a supply of browse; if she did not get the grass she became extremely agitated.

When the white rhino were brought back to the bomas they had to be kept under constant observation while recovering from the drugs; they had a habit of getting their horns jammed in corners of the pens and suffocating to death. This happened particularly during the early period when Sernyl was included in the drug combination. Some bomas were constructed of creosoted poles, but this was discontinued as creosote seems to irritate the white rhino and to induce serious skin disorders. Rhino in the field seem to have a rooted objection to creosoted poles, and invariably knock them over.

Reactions immediately after coming round from the drug seldom varied. A sudden noise of any kind would make them charge in the direction of the sound, and if a human walked up to the boma gate the rhino would charge, but nearly always stop just before hitting it; only the occasional animal would hit the gate with its horn. With the constant construction work going on around pens it was found that the rhino were always nervous and took longer to tame, until Ranger 
Clark started playing a transistor radio. This was switched on when the rhino was brought in and left on for a minimum of seventy-two hours; this accustomed the animal to noise which speeded up the taming period considerably.

In the open pens red-billed oxpeckers Buphagus erythrorhynchus would perch on the rhino to feed on the ticks as they do in the wild. Rhino that had been subjected to the taming process for a week or more ceased to react to the alarm call of the oxpecker. Rhino that were given a great deal of attention tamed faster than others and would come to the boma gates to be scratched with hard brooms. One rhino seemed bored in the pens and spent much of the day pushing lucerne from one side to the other (Steele pers. comm.). Whenever possible the crate in which the animal was going to travel was placed in front of the pen, and the animal fed in it.

\section{Females More Difficult Than Males}

Clark (pers. comm.) says that females are more suspicious and take longer to tame than males. They could never really be trusted even though they appeared tame, and he would never go into a pen containing a female. One female suffering from colic was fed with bottles of cereal protein and concentrates, and Clark was in the pen with it daily for over three weeks, during which time it was completely tame and dependent. But once it had recovered it was dangerous to stay in the pen. The male, once it trusts someone, can be handled easily, even to waking it from a deep sleep, and it remains peaceable even while being loaded on to a truck and pushed around. Recent developments include putting two animals together during the taming period in an area that includes boma and eighty-yard paddock. Putting two females together is a sure way to cause trouble, but it is possible to put a male and female together, or two males; two females of any age except the youngest usually fight.

There were some animals which refused to accept captivity; although eating and drinking well, they would continue to fight the pen until they had no skin on their heads. One illustration of this is interesting. A young, $1500 \mathrm{lb}$ animal still with the cow, was often observed near the boma. It was unconcerned about passing vehicles and hardly bothered to look up when anyone approached to within 20 yards, so when a rhino was needed in a hurry for export, this one was captured. It started eating after the normal interval, but instead of settling down in the usual way, it grew more determined to get out, skinned itself on the forehead and front legs, pulled off the front horn and ripped toe nails loose. After three weeks we decided to release it before it injured itself further. Next day it was seen with the cow, once again unconcerned about vehicles or anyone who went near it.

Another rhino of $1700 \mathrm{lb}$ refused to eat at all in captivity, so after two weeks of starvation it was tagged and released. Within 200 yards of the boma it began eating and continued all day. Two months later 
it was accidentally recaptured but spent all day attacking the fence cable, mainly at the point where it had once before been released, and after three weeks it had to be released again.

Some captured rhino simply sulk, and one can do nothing to stop them. Even letting them into an emergency paddock with standing grass two feet high makes no difference. In the end they have to be released because they get so weak they can hardly stand.

Partially tamed rhino react to wild ones passing in the night so much that they will stop eating for as much as a week. They keep calling to each other and the captive runs up and down trying to get out. One female of $4000 \mathrm{lb}$ named Masinyane (Zulu-the one who hurries) was in oestrus when captured. A male kept within sight during the day, and at night tried to rip the boma to pieces; the staff had to spend most of the night chasing it away. Eventually this cow was taken to Ndumu Game Reserve and put into a big cabled paddock prior to release into the game reserve. Within twenty-four hours the first male ever released at Ndumu knocked down the cable and took the cow away. It was the first animal to calve there.

Horns breaking off has been a frequent occurrence, but an application of stockholm tar aids healing, as do acriflavine and glycerine.

\section{Transport by sea}

Clark, who has accompanied seven animals to the United States, says the animals were not disturbed by bad weather (pers. comm.). On three occasions during the trip, water was running eighteen inches deep through the crates, but the rhino were not unduly alarmed. Once it was so rough they had to go without food for two days, and even this did not over-concern them. L. Rhue of West Germany, in a letter to Steele (September, 1964) mentions that for several days during a storm the animals he was taking to Hamburg had to stand in $2 \frac{1}{2}$ feet of sea water, day and night. The journey also entailed extreme climatic conditions-very cold on departure from Durban and very hot on arrival at Hamburg. On Clark's first journey via the east coast of Africa, the rhino suffered with the heat in the Suez Canal and were also excited by the smell of the land. After weeks at sea they always reacted the moment a land wind blew. He found that placing the crates head to head seemed to alleviate boredom and calmed the animals.

\section{Translocations to other Game Reserves}

Mkuzi Came Reserve, Zululand. The first rhino to be moved to Mkuzi in a drugged state was in 1961 when we were experimenting with the Themalon drug combination. A young female was captured in the west of Umfolozi Game Reserve and taken to Mkuzi Game Reserve, 100 miles north. Heavy rain fell during the journey, the truck got stuck, and the rhino had to stay in the crate for twenty-four hours while we struggled to get the truck out of the mud. The rhino cut its foot on release and subsequently died of blood poisoning. 
Altogether in 1961 ten animals, including a fully grown female, were captured and transported to Mkuzi, but only four remain within the boundaries of the reserve. Poachers accounted for the majority.

Ndumu Game Reserve, Zululand. Eighteen white rhino, ten bulls and eight cows, have been moved to Ndumu Game Reserve since 1961, and have settled down well in what is an ideal habitat. Initially they were released into bomas and then into large paddocks, but this practice was discontinued. Within the reserve, two rivers, the Usutu and the Pongolo, join and when they overflow create many pans. There is an abundance of grazing along the pan fringes, much of it cropped to a suitable height by the resident hippo and patches of dense bush give both adequate shade and cover for calving. The reserve is small (25,000 acres), but only three rhinos have tried to get out.

Six white rhino have died in the operation. One male died en route to Ndumu, due to a following wind blowing the fumes from a badly placed exhaust pipe into the crate, and another young male was stuck in the mud and drowned. Two females were drowned shortly after release while trying to cross the Pongola river, and a third got out of the reserve, headed in a southerly direction and was shot by African poachers. A calf born in the reserve was takev and killed by a crocodile-the only record in Zululand of predation by crocodile. Against this there have been six births, leaving the number of white rhino in Ndumu at 18.

\section{Willem Pretorius Came Reserve, Orange Free State.}

In March, 1962, the first four white rhino were introduced into the Orange Free State. They were taken, drugged, on a journey of more than 400 miles from the Zululand low veld at only 800 feet over the Drakensberg mountains at 6,000 feet, in driving rain and bitter cold, and arrived in good condition. Since then four more have been translocated with no mortality, and two births have been reported.

Kruger National Park. A large male was introduced into the squaremile paddock containing the original four sent in 1961, but the first rhino male had obviously established its territory, and serious fighting broke out. The newcomer received a bad gash and a deep hole on the right hind leg, some of the muscles being completely severed, and had to be destroyed, (Brynard in litt. 1962). Two calves have subsequently been born in the paddock (Brynard pers. comm.). Between June 23rd, 1962, and September 29th, 1964, 92 white rhino were transported to the Kruger National Park. All were crated after capture and transported straight to the Park, a journey of approximately 300 miles.

After October 1962, the National Park authorities decided to release the rhino straight into the field. One large male was attacked by lions, badly injured and had to be destroyed, and another was attacked but got the better of the fight. Brynard, Nature Conservator in the Kruger, described one incident after release when a Game Ranger on patrol came upon a dead white rhino bull killed by an elephant at a water 


\section{Table 1; Destination of 499 White Rhinoceros immobilised in Umfolozi Game Reserve}

$\begin{array}{lcccccr}\text { To zoos } \ldots & \ldots & \ldots & \ldots & \ldots & \ldots & 63 \\ \text { To other game reserves in Southern } & \text { Africa } & \ldots & 330 \\ \text { Marked and released for study } & \ldots & \ldots & 43 \\ \text { Deaths in captivity } & \ldots & \ldots & \ldots & \ldots & 41 \\ \text { Deaths during capture } & \ldots & \ldots & \ldots & 10 \\ \text { Deaths due to drugs } \ldots & \ldots & \ldots & \ldots & 2\end{array}$

hole near Shingwedzi in the north of the Kruger National Park. From the surrounding spoor he reconstructed the fight. The two huge combatants had fallen down a 100 -foot embankment, but the rhino had refused to give way. An inspection of this rhino carcass revealed that it had been severely gored by both tusks on one side and had two deep wounds from single tusk stabs.

Brynard states that rhino released north of the Sabie river had wandered furthest. Four had crossed into Portuguese East Africa, including one which crossed the border near Shingwedzi and went as far north as the Limpopo. The rhino released south of the Sabie river wandered, but not to the same extent as those to the north. One female went into Portuguese East Africa and was killed by poachers, while another was drowned shortly after release. Some rhino released in the Crocodile Bridge area walked as far as Skukuza, 40 miles away, and remained in the area for a few days, then returned to the point of release. Ten calves have been recorded but it is not known how many of these were conceived in Umfolozi Game Reserve prior to translocation (Brynard pers. comm.).

\section{Matapos Park and Kyle Dam Reserve}

The first eight rhino translocated to Rhodesia in 1962 were tamed down prior to removal; four were put in the Matopos National Park and four in the Kyle Dam Game Reserve. For the journey of 1200 miles, the rhino left Umfolozi Game Reserve at 0800 hours on August 30th and arrived at their destination at 1200 hours on September 3rd. By the end of 1965, with the development of land adjoining the Umfolozi Game Reserve for African settlement, it became urgent to remove all the white rhino, and the Rhodesian wildlife authorities thankfully accepted a donation of 100 white rhino for their parks. The expense of keeping the rhino in bomas prior to translocation was too great for either the Natal Parks Board or the Rhodesian wildlife authorities, so it was decided to experiment with moving drugged rhinos 800 miles immediately after capture. The first, a young male of $2500 \mathrm{lb}$ was moved in February 1966, in 28 hours of continuous driving. (Immobilising doze: $4 \mathrm{mgm} \mathrm{M99,} 100 \mathrm{mgm}$ hyocine, $4 \mathrm{mgm}$ Acetylpromazine). A total of $15 \mathrm{cc}$ at $50 \mathrm{mgm}$ per cc Largactil (chlorpromazine hydrochloride) was administered during the journey. (Rochat, unpublished report, March 1966). The second rhino, an 


\section{Table 2: Growth of two juvenile White Rhinos in Umfolozi Game Reserve determined by marking and recapture}

\begin{tabular}{|c|c|c|c|c|c|}
\hline & \multicolumn{3}{|c|}{ MALE (Tommy) } & $\begin{array}{l}\text { FEM } \\
\text { Est. age in }\end{array}$ & $\begin{array}{l}\text { ALE } \\
\text { months }\end{array}$ \\
\hline & $12 \mathrm{~m}$. & $27 \mathrm{~m}$. & $34 \mathrm{~m}$. & $18 \mathrm{~m}$ & $30 \mathrm{~m}$. \\
\hline Horn, anterior & 6 & $9 \frac{5}{8}$ & $11 \frac{1}{2}$ & $8 \frac{1}{4}$ & $12 \frac{1}{4}$ \\
\hline Horn, posterior & forming & $2 \frac{1}{4}$ & $2 \frac{1}{4}$ & $1 \frac{3}{4}$ & $3 \frac{1}{4}$ \\
\hline Head $\quad \ldots \ldots \ldots \ldots \ldots \ldots \ldots$ & 23 & 31 & $30 \frac{1}{2}$ & 22 & $29 \frac{1}{2}$ \\
\hline Occiput to base of tail ... & 68 & 86 & 89 & $75 \frac{1}{2}$ & $84 \frac{1}{2}$ \\
\hline Tail $\ldots \ldots \ldots \ldots \ldots \ldots \ldots \ldots \ldots$ & 11 & 22 & $23 \frac{3}{4}$ & 17 & $22 \frac{1}{4}$ \\
\hline Heart girth (in full) ......... & $74 \frac{1}{2}$ & 89 & 95 & 81 & 100 \\
\hline Height at shoulder & $48 \frac{1}{2}$ & 55 & $59 \frac{1}{2}$ & 44 & 52 \\
\hline 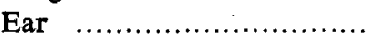 & 8 & $9 \frac{3}{8}$ & $9 \frac{1}{2}$ & 9 & 9 \\
\hline
\end{tabular}

adult female of $3500 \mathrm{lb}$ was taken on March 7th, 1966 (Rochat, op. cit.). During the 26-hour journey it had alternating periods of depression and alertness, and as a result of leaning against the crate door, it partially detached the anterior horn. On arrival at Kyle Dam it attempted to escape through the top of the crate and became violent, but when released it became indifferent, drank water and lay down. An initial dose of $10 \mathrm{ccm}$ Largactil was sufficient for the first ten hours of the journey, thereafter 3 to $5 \mathrm{cc}$ at $50 \mathrm{mgm}$ per cc as required. The total dosage was $30 \mathrm{ccm}$.

On August 14th, the third, a young male of $3000 \mathrm{lb}$ was captured with $2 \mathrm{mgm}$ M99, $100 \mathrm{mgm}$ hyocine and $4 \mathrm{mgm}$ Acetypromazine. During the 30-hour journey it was given $1 \mathrm{gm}$ Themalon and $20 \mathrm{cc}$ at $50 \mathrm{mgm}$ per $\mathrm{ccm}$ Largactil. The addition of Themalon apparently enabled it to travel more comfortably, and only right at the end of the journey did it lose its horn. All three animals were given $10 \mathrm{gm}$ Streptomycin. During these long journeys rhino will stand up, moving backwards or forwards, or lie down. When coming round from the drug they can be very violent, and slow down the truck by their movements; they even try to climb out of the opening in the top of the crate. Animals travel decidedly better with their tails to the engine. Six more rhino have been transported in an identical manner without loss, and the operation will continue until 100 have been moved. The rapid method of translocation has undoubtedly saved the lives of rhino which would otherwise have had to be shot.

\section{Marking for release and further study}

Forty-three animals have been captured, tagged and released for further study. Two of them, an 18-month-old female and 1-year-old male, were subsequently recaptured and remeasured. (See Table 2).

The first adult male successfully immobilised (December, 1960) was tagged in the ear with easily identifiable green streamers which remained in position for four months. This animal was followed by the writer and notes made of habitat and behaviour. It defended its 

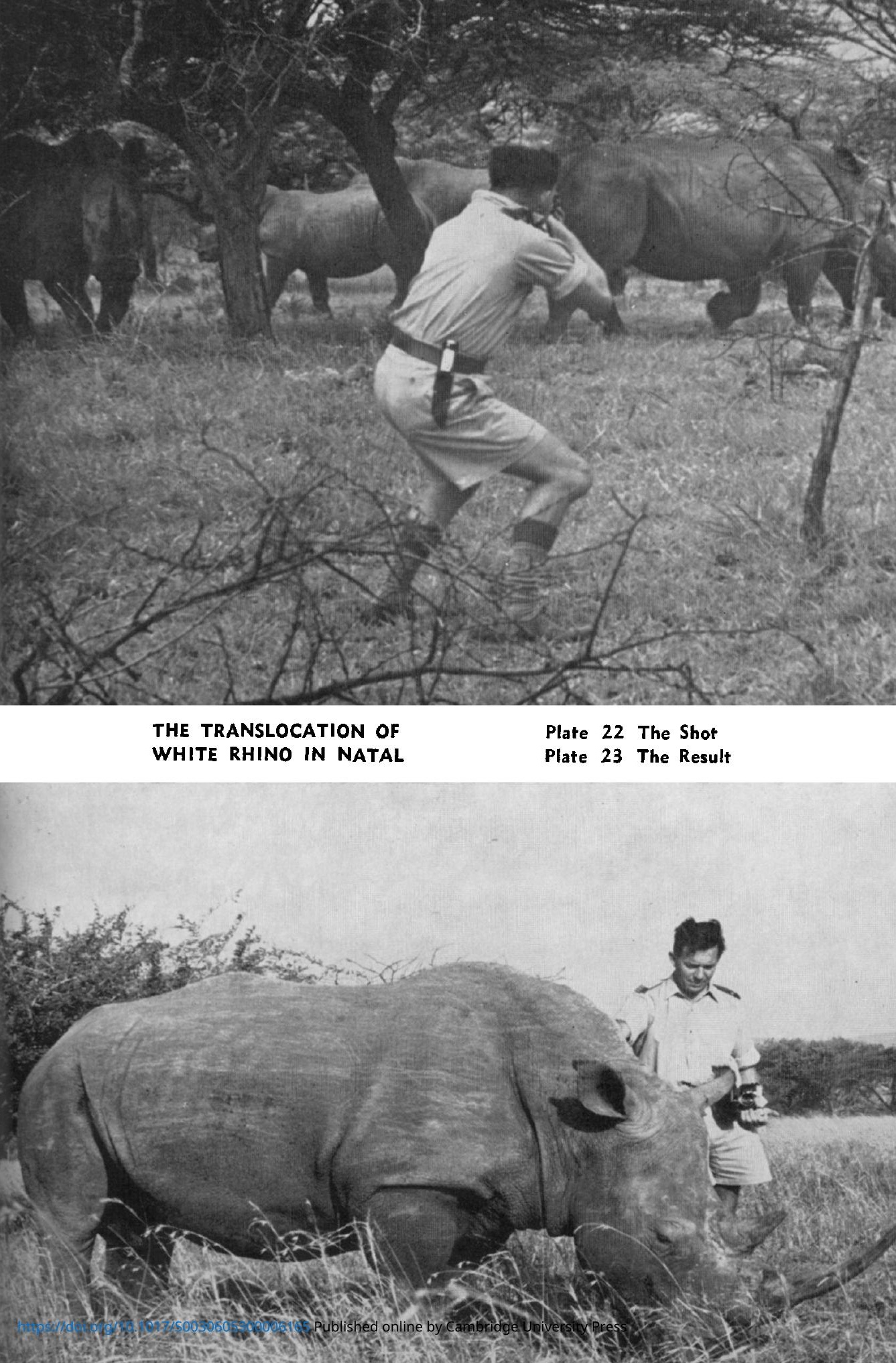


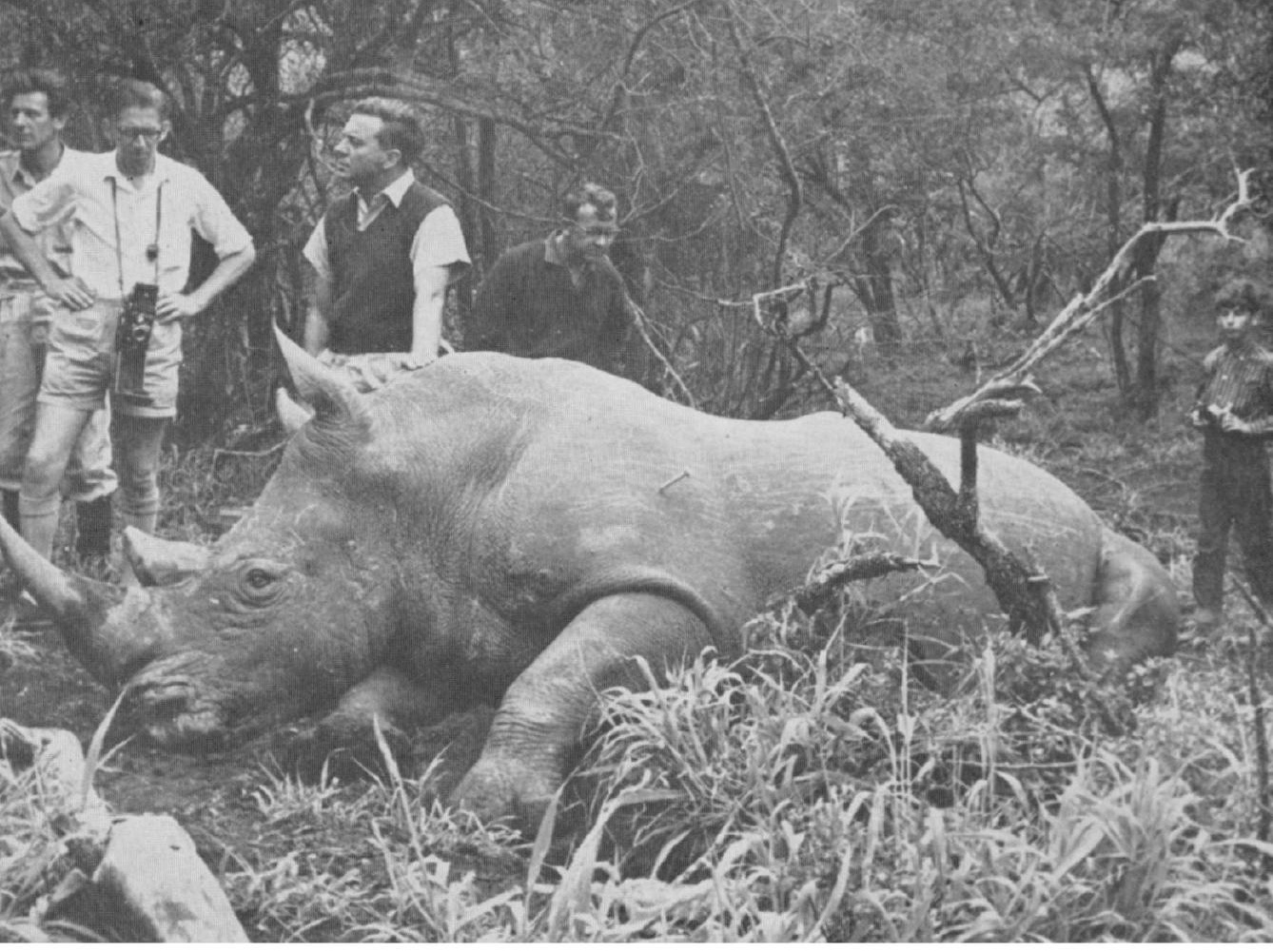


Plate $\mathbf{2 8}$

THE RIDE UP THE

ROLLERS

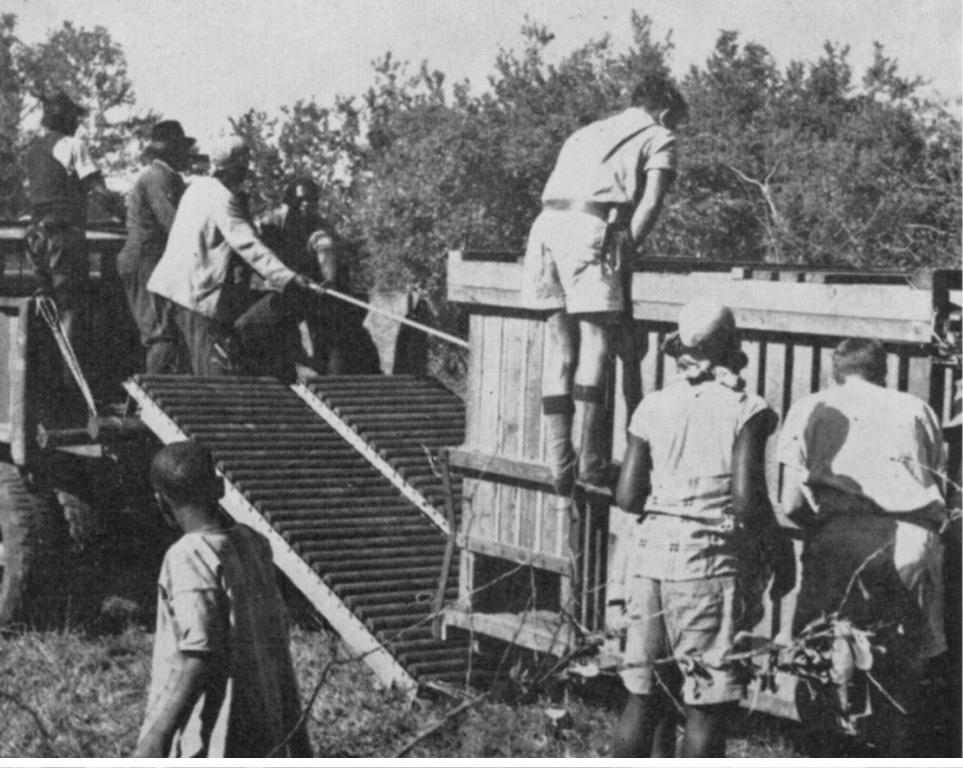

Plate 29

RELEASE AT LAST

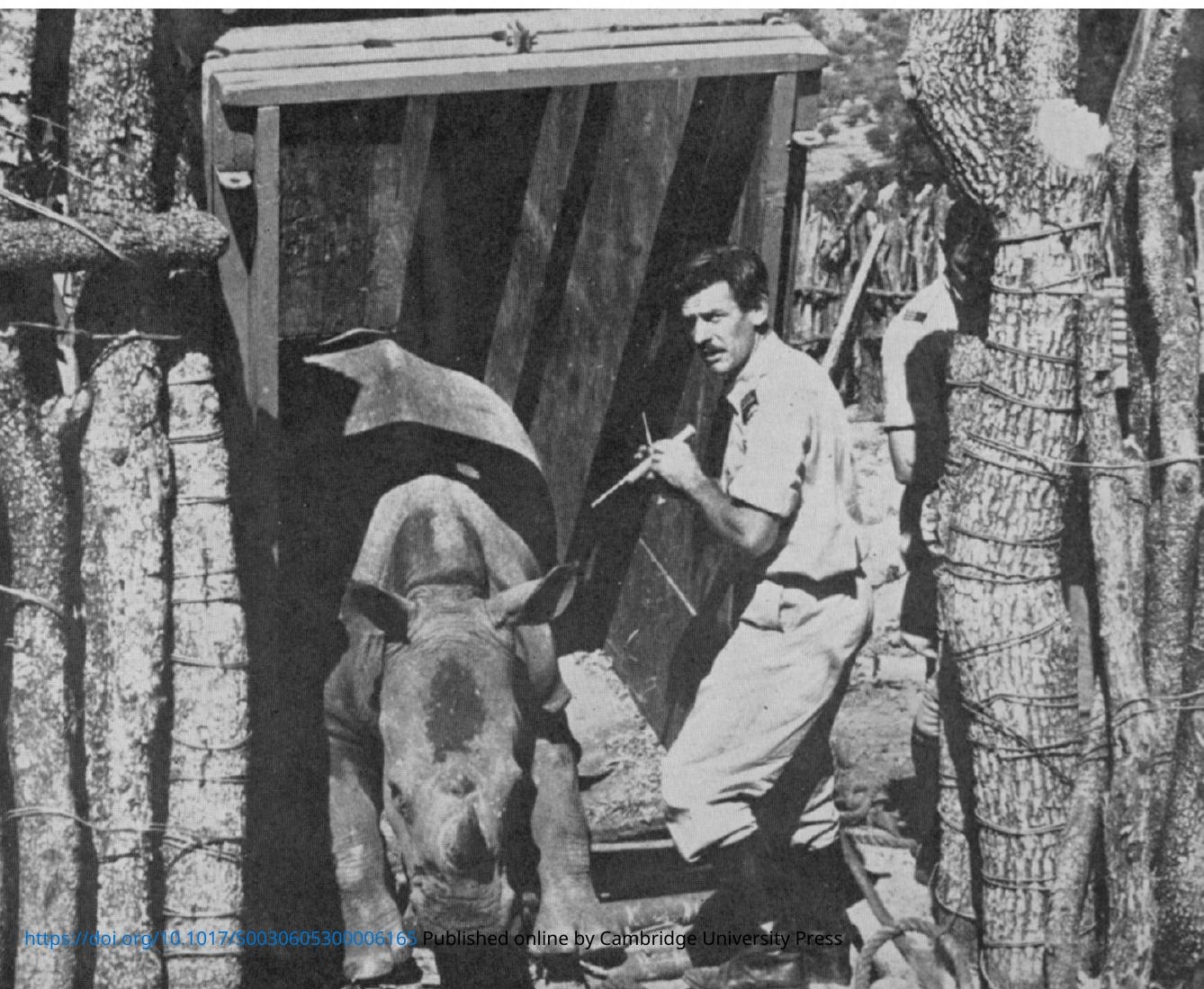




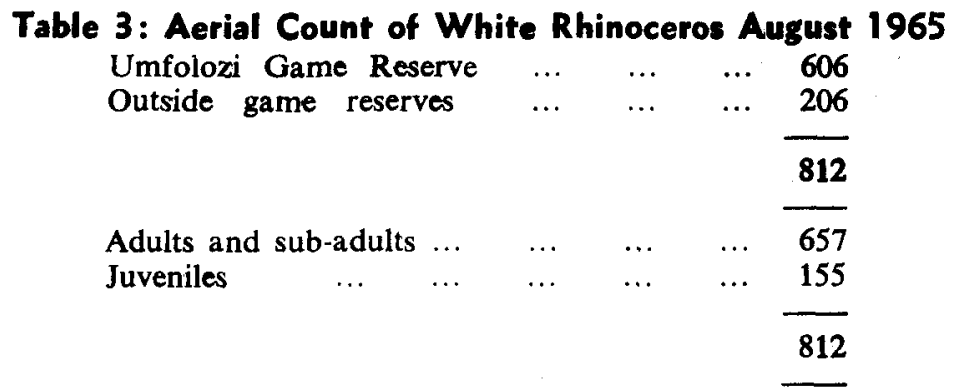

territory aggressively against other males, and when a female entered its territory made every effort to keep her from moving out. Steele mentions that this habit is useful in capturing females within a male's territory, for the male prevents the female from running after it is darted (pers. comm.). Adult males that have been darted and have run into other males' territories have been attacked after preliminary warnings from the resident males. On one occasion in 1961 (personal observation) a resident male charged an intruding darted male and forced it into a deep ditch. Only by shouting repeatedly and blowing a vehicle hooter was it possible to get the attacker to desist.

Capture of Black Rhino

Since 1961 we have been carrying out a programme of capture and translocation of black rhino from unreserved areas in Zululand to game reserves, and black rhino injured in snares have also been captured, treated and released. Three black rhino were captured with morphine or Themalon plus hyocine and Largactil; two died. Four animals were captured with morphine or Themalon plus hyocine, Largactil and Sernyl; one died. Seventeen animals were captured with M99, hyocine and Acetylpromazine; two died. Dosage of M99 is 3 mgm for a $2200 \mathrm{lb}$ animal or $1 \mathrm{mgm} \mathrm{M99}$ per $700 \mathrm{lbs} .3 .5 \mathrm{ccm}$ of Taractan at $50 \mathrm{mgm}$ per cc must be adrinistered 15 to 20 minutes prior to the injection of Lethidrone required to get the animal up onto its feet in the crate (Clark in litt.). Ten black rhino were translocated to the Ndumu Game Reserve, of which eight survived; one calf was born recently, giving a total of nine.

Summary

1. The history and distribution of the white rhino is briefly outlined to indicate the reasons for translocation.

2. External physical characteristics differentiating the white rhino from the black rhino are detailed.

3. Procedures and techniques for capture, transport and keeping in captivity in Umfolozi Game Reserve, are described.

4. The translocation of white rhino within southern Africa undertaken between 1961 and September 1966 is detailed and illustrated together with the behaviour and history of animals released into 
former habitats. Brief observations of marked and recaptured animals in the Umfolozi Game Reserve are given, together with details of the most recent census.

\section{Acknowledgments}

Without the oustanding pharmacological, physiological and veterinary knowledge of $\mathrm{Dr}$. A. M. Harthoorn of the University College of East Africa, the translocation of the white rhino could never have been a success. It has been due entirely to Dr. Harthoorn that so much progress has been made in the use of various drugs. Of the many Game Rangers of the Natal Parks Board who have been a part of the Rhino Capture Team, acknowledgment must be made to N. A. Steele, currently Senior Warden in Zululand, Rangers John Clark, John Tinley, Ken Rochat and the late Owen Letley. It is also impossible not to mention Colonel J. Vincent former director of the Natal Parks Board, and Mr John Geddes-Page, currently director of the Board, for their administrative ability and encouragement to the field officers by ensuring a steady flow of materials. I am also indebted to my old colleague J. F. Feely, who gave valuable advice on the preparation of this paper. Finally thanks are due to John Vincent, Research Officer Hluhluwe Game Reserve, for his careful scrutiny of the final draft.

\section{Literature cited}

1. Player I. C. and J. M. Feeley 1960: A preliminary report on the square-lipped rhinoceros Ceratotherium simum simum. The Lammergeyer 1 (i): 3-23.

2. Lang H., (n.d.): Preservation, occurrence and habits of the white rhinoceros Ceratotherium simum simum. Unpublished report.

3. Alexander A. and Player I. C. 1965: A note on the nuchal hump of the square-lipped rhinoceros Ceratotherium simum simum (Burchell). The Lammergeyer 3 (2): 5-9.

4. Harthoorn, A. M. 1962: The capture and relocation of the white (square-lipped) rhinoceros Ceratotherium simum simum. The Lammergeyer 2 (2): $1-9$.

5. Harthoorn, A. M. 1963: The value of neuroleptic narcosis in restraint: compared with that of anaesthesis, sedation or paralysis. Read at Symposium on African Mammals, Salisbury 26-28 September, 1963.

6. Harthoorn, A. M. 1965: Application of pharmacological and physiological principles in restraint of wild animals. Wildlife Monographs 14.

7. Davison, E. and Condy J. B. 1963 The importation of eight square-lipped rhinoceros Ceratotherium simum simum to Southern Rhodesia. Natural Resources Board, Salisbury. 